\title{
TINJAUAN YURIDIS TENTANG PENYELESAIAN SENGKETA KONSUMEN
}

\author{
JURIDICAL REVIEW OF CONSUMER \\ DISPUTES RESOLUTION
}

\author{
Abdul Rahman Tibahary \\ (Email :arie_recht@yahoo.com)
}

\begin{abstract}
ABSTRAK
Lahirnya Undang-Undang No. 8 Tahun 1999 tentang Perlindungan Konsumen merupakan angin segar bagi konsumen untuk mempertahankan haknya apabila dirugikan oleh pelaku usaha. Konsumen dapat melakukan gugatan melalui peradilan umum atau pada Badan Penyelesaian Sengketa Konsumen untuk menyelesaikan sengketa konsumen, baik dengan secara konsiliasi, mediasi, ataupun arbitrase. Studi ini adalah penelitian hukum normatif yang ditunjang oleh data empiris. Sebagai bahan analisis dengan menggunakan pendekatan konseptual dan pendekatan statuta. Dalam pembahasan dipergunakan teori legal sistem dari Friedman dan teori penegakan hukum dari Soerjono Soekanto. Hasil penelitian menunjukkan bahwa baru dibentuk 27 BPSK yang berkedudukan di kabupaten dan kota di seluruh Indonesia, dengan demikian usaha perlindungan konsumen belum sesuai dengan yang diharapkan karena belum semua di kabupaten atau kota di tempat tinggal konsumen dibentuk BPSK sehingga apabila konsumen mau menggugat harus ke BPSK terdekat di luar tempat tinggal konsumen.
\end{abstract}

Kata Kunci : Penyelesaian Sengketa Konsumen

\section{ABSTRACT}

Birth of Law No. 8 of 1999 concerning Consumer Protection is a breath of fresh air for consumers to defend their rights if harmed by business actors. Consumers can make a lawsuit through the general court or the Consumer Dispute Settlement Agency to resolve consumer disputes, either by conciliation, mediation or arbitration. This study is normative legal research supported by empirical data. As an analysis material using a conceptual approach and statute approach. In the discussion used Friedman's legal theory and the theory of law enforcement from Soerjono Soekanto. The results of the study showed that only 27 BPSK were established in regencies and cities throughout Indonesia, thus the consumer protection business was not as expected because not all in the regency or city in the consumer's residence were formed BPSK so that if consumers want to sue the nearest BPSK outside the consumer's residence.

Keywords: Consumer Dispute Resolution 


\section{PENDAHULUAN}

Indonesia termasuk negara yang berkembang, baik dalam pembangunan dan perkembangan perekonomian nasional telah menghasilkan beraneka ragam produk barang dan/atau jasa yang dapat dipakai dan dimanfaatkan oleh masyarakat. Kemajuan dibidang ilmu pengetahuan, teknologi telekomunikasi dan informatika juga turut memperluas ruang transaksi barang dan/atau jasa hingga melintasi batas wilayah suatu negara. dengan demikian sangat bermanfaat bagi kepentingan konsumen karena kebutuhan barang dan/atau jasa yang diinginkan dapat terpenuhi, dalam hal ini konsumen memiliki hak untuk memilih aneka jenis kualitas barang dan/atau jasa sesuai dengan nilai tukar dan kondisi serta jaminan yang dijanjikan.

Kedudukan konsumen pada umumnya masih lemah dalam bidang ekonomi, dan pendidikan. Untuk dapat menjamin suatu penyelenggaraan perlindungan konsumen, maka pemerintah membuat Perlindungan Konsumen dalam suatu produk hukum. Hal ini penting karena hanya hukum yang memilki kekuatan untuk memaksa pelaku usaha untuk menaatinya, dan juga hukum memiliki sanksi yang tegas. dampak yang dapat ditimbulkan akibat tindakan pelaku usaha yang sewenang-wenang dan hanya mengutamakan keuntungan dari bisnisnya sendiri, maka pemerintah memilki kewajiban untuk melindungi konsumen yang posisinya memang lemah.

Dengan adanya Undang-Undang Perlindungan Konsumen, maka masyarakat konsumen yang dirugikan terlindungi dan mempunyai pilihan untuk mengadukan permasalahannya dengan mengajukan gugatan ke pengadilan negeri, atau dapat mengajukan kepada Badan Penyelesaian Sengketa Konsumen. Pembentukan hukum perlindungan konsumen tidak dimaksudkan untuk mematikan usaha para pelaku usaha, tapi bertujuan untuk meningkatkan kualitas pelayanan barang dan/atau jasa yang disediakan oleh pelaku usaha.

Badan Penyelesaian Sengketa Konsumen wajib mengeluarkan putusan paling lambat dalam waktu dua puluh satu hari kerja setelah gugatan diterima serta dalam waktu paling lambat tujuh hari kerja sejak menerima putusan, para pihak dapat mengajukan keberatan kepada Pengadilan Negeri paling lambat empat belas hari kerja sejak menerima pemberitahuan putusan, kepada pelaku usaha yang tidak mengajukan keberatan dalam jangka waktu paling lambat empat belas hari kerja sejak menerima pemberitahuan putusan dianggap menerima putusan Badan Penyelesaian Sengketa Konsumen.

Yayasan Lembaga Konsumen Sulteng memberi waktu 14 hari atau selama dua pekan atas tanggapan somasi yang diajukan 5 Februari 2007. Hingga batas akhir Senin 19 Februari 
2007 lalu, tanggapan tidak ada. Salman Hadiyanto menuturkan, himbauan yang dituangkan melalui somasi, juga sedang diperjuangkan YLKI Pusat Jakarta untuk diadvokasi di PT PLN. tim bidang pengaduan YLKI pusat datang ke Palu untuk peninjauan sekaligus menghitung tingkat kerugian yang dialami konsumen. Hasilnya sebagai rujukan untuk mengadukan PT PLN pusat. Jika memang tidak membuahkan hasil, ditegaskan Salman, class action akan diajukan.

Berdasarkan uraian latar belakang, maka permasalahan yang akan dibahas oleh penulis, adalah sebagai berikut : 1). Bagaimanakah sikap badan peradilan dalam memberikan upaya perlindungan konsumen? 2). Faktor yang menjadi penyebab kendala dalam mengimplementasikan Undang-Undang Perlindungan Konsumen?

\section{METODE PENELITIAN}

Metode penelitian yang digunakan dalam penulisan ini adalah normatif. Tahap penelitian yang dilakukan penulis adalah penelitian kepustakaan yaitu penelitian yang dilakukan dengan menghimpun dan mempelajari buku, literatur, dokumen, peraturan perundang-undangan serta artikel yang berkaitan dalam mendukung penulisan ini. Bahan Hukum tersebut antara lain adalah Bahan hukum primer, merupakan bahan hukum yang mengikat: 1). Undang-Undang Republik Indonesia Nomor 8 Tahun 1999 tentang Perlindungan Konsumen. 2). Undang-Undang Republik Indonesia Nomor 30 Tahun 1999 tentang Arbitrase dan Alternatif Penyelesaian Sengketa. 3). Keputusan Menteri Perindustrian dan Perdagangan Republik Indonesia No.350/MPP/Kep/12/2001 tentang Pelaksanaan Tugas dan Wewenang BPSK. Bahan hukum sekunder, yaitu bahan-bahan yang memberikan penjelasan mengenai bahan hukum primer, seperti artikel, makalah, hasil karya ilmiah dibidang hukum, dan tulisan-tulisan yang banyak terdapat pada seminar, majalah, surat kabar, dan internet.

\section{HASIL DAN PEMBAHASAN}

\section{A. Sikap Badan Peradilan dalam Hubungannya dengan Perlindungan Konsumen}

Pemerintah dalam upaya memberikan perlindungan hukum terhadap konsumen yang sering dirugikan oleh pelaku usaha, maka konsumen dalam mencari perlindungan hukum dapat mengajukan gugatan ke badan peradilan umum yang berada dalam wilayahnya. Beberapa cara untuk konsumen dalam melakukan pengajuan gugatan terhadapa pelaku usaha: 
1. Pengajuan gugatan secara perdata diselesaikan menurut instrumen hukum perdata

Gugatan perdata ini diajukan melalui pengadilan negeri ditempat kedudukan konsumen. Dengan berlakunya Undang-Undang Perlindungan Konsumen, maka konsumen yang akan mengajukan gugatan kepada pelaku usaha, tidak mengajukan gugatan melalui pengadilan negeri ditempat kedudukan pelaku usaha yang menjadi tergugat, sebagaimana yang diatur dalam Pasal 118 HIR, tetap diajukan kepada pengadilan negeri ditempat kedudukan konsumen sebagai penggugat.

2. Penyelesaian sengketa konsumen melalui instrumen hukum Pidana.

Sanksi pidana dalam Undang-Undang Perlindunngan Konsumen dalam batas-batas tertentu dipandang sepadan dengan kebutuhan untuk melindungi dan mempertahankan kepentingan-kepentingan tersebut, yang secara lebih khusus kepentingankepentingan itu dirumuskan dalam hak-hak konsumen. Adanya sanksi perdata dan sanksi administrasi negara dalam Undang-Undang Perlindungan Konsumen merupakan sarana nonpidana, yang diharapkan memiliki pengaruh preventif. Hukum pidana baru digunakan, bila instrumen-instrumen hukum lainnya sudah tidak berdaya lagi untuk melindungi konsumen.

3. Penyelesaian sengketa konsumen melalui instrumen hukum Tata Usaha Negara.

Pasal 45 Ayat (1) dan Pasal 46 Ayat (2) Undang-Undang Perlindungan Konsumen terkesan hanya membolehkan gugatan konsumen ini diajukan dilingkungan peradilan umum. Pembatasan ini jelas menghalangi konsumen yang perkaranya mungkin menyentuh kompetensi peradilan Tata Usaha Negara. jika konsumen diartikan secara luas, yakni mencakup juga penerimaan jasa pelayanan publik, tentu peradilan Tata Usaha Negara seharusnya juga patut melayani gugatan tersebut. Untuk itu perlu diperhatikan, bahwa syaratsyarat bersengketa itu berawal dari adanya penetapan tertulis, bersifat kongkrit, individual dan final harus tetap dipenuhi.

\section{B. Kendala yang dihadapi dalam mengimplementasikan Undang-Undang Perlindungan Konsumen}

Selama ini konsumen di Indonesia seringkali berada dalam posisi yang terpaksa harus mengalah jika berhadapan dengan pelaku usaha meskipun mendapatkan barang atau jasa yang jauh dari apa yang konsumen harapkan. Sehingga jika konsumen dirugikan jarang diantara mereka yang sadar untuk menuntut ganti rugi kepada pelaku usaha terutama melalui jalur hukum. Beberapa kendala yang mendasarinya, antara lain: 


\section{Aspek Budaya Hukum.}

Adanya sikap masa bodoh dan malas berperkara di pengadilan dari sebagian besar masyarakat di Indonesia, terutama konsumen yang kurang paham mengenai permasalahan hukum. Sehingga jika dirugikan oleh pelaku usaha, konsumen tersebut tidak tau harus berbuat apa dan melapor kepada siapa. Konsumen seperti ini biasa disebut man in the street. Adapun konsumen yang paham mengenai hukum, tetapi karena berperkara di pengadilan membutuhkan biaya dan waktu yang cukup lama. Akhirnya konsumen tersebut tidak jadi menempuh jalur hukum.

2. Masih kurangnya Sosialisasi Undang-Undang tentang Perlindungan Konsumen kepada masyarakat.

Dalam upaya untuk menuju perlindungan konsumen, perlu dilaksanakannya pembinaan dan penyuluhan yang berkesinambungan dari berbagai instansi/departemen teknis seperti Departemen Perindustrian dan Perdagangan, Departemen Kesehatan yang ditujukan kepada masyarakat yang berada dalam lingkup pembinaannya.

3. Masih kurangnya komitmen pemerintah dalam melindungi konsumen.

Dalam kehidupan sehari-hari banyak hal yang sangat merugikan atau bahkan membahayakan konsumen. Namun apabila dilaporkan kepada instansi yang berwenang kurang mendapat tanggapan yang memadai dengan berbagai macam alasan. Hal ini mengakibatkan kasus yang diajukan menjadi terbengkalai dan kasus lain yang serupa akan terulang terus-menerus.

Keterkaitan pemerintah dalam menyelenggarakan perlindungan konsumen merupakan faktor penentu, karena pemerintah mempunyai kewajiban untuk melindungi warganya terhadap tindakan sewenang-wenang pelaku usaha, baik nasional maupun internasional yang dapat menimbulkan kerugian, yang dalam lingkup luas adalah kepentingan nasional dan dalam lingkup sempit adalah konsumen.

\section{KESIMPULAN DAN SARAN}

Penyelesaian sengketa konsumen menurut Undang-Undang No. 8 Tahun 1999 tentang Perlindungan Konsumen. Sudah sesuai dengan apa yang diharapkan konsumen selama ini, namun semua itu bergantung pada sikap badan peradilan dalam menerima perkara sengketa konsumen dan sikap pemerintah dalam memberikan perlindungan terhadap konsumen. Dan Adanya pertentangan Undang-Undang Perlindungan Konsumen dengan UU No. 30 Tahun 1999 tentang Arbitrase dan Alternatif Penyelesaian Sengketa, karena Undang-Undang Perlindungan konsumen membuat suatu aturan penyelesaian sengketa konsumen ynag 
tersendiri, yang relatif berbeda dengan konsep dasar mekanisme arbitrase yang berlaku umum, sehingga penyelesaian sengketa konsumen menjadi berlarut-larut. Perangkat peraturan dalam Undang-Undang Perlindungan Konsumen, memperlihatkan kemajuan berkenaan dengan adanya pengaturan class action dan legal standing, sehingga kelompok konsumen yang menjadi korban, dapat mengajukan gugatan kelompok atau dimungkinkan adanya gugatan yang diajukan oleh Yayasan Lembaga Konsumen Indonesia atau Lembaga Perlindungan Konsumen Swadaya Masyarakat untuk kepentingan konsumen secara umum.

Saran yang direkomendasikan peneliti Memperbanyak Badan Penyelesaian Sengketa konsumen daerah tingkat II, khususnya untuk Kota Palu yang belum ada BPSK. Dan Budaya hukum perlu disosialisasi mengenai hukum perlindungan konsumen baik kepada masyarakat luas, maupun melalui pendidikan sejak awal.

\section{DAFTAR PUSTAKA}

Keputusan Menteri Perindustrian dan Perdagangan Nomor 350/MPP/Kep/12/2001, tentang

Pelaksanaan Tugas dan Wewenang Badan Penyelesaian Sengketa Konsumen.

Undang- Undang Dasar 1945, amandemen tahun 1999 dan tahun 2000.

Undang- Undang No. 8 Tahun 1999 tentang Perlindungan Konsumen.

Undang- Undang No. 30 Tahun 1999 tentang Arbitrase dan Alternatif Penyelesaian Sengketa. 